\title{
Últimos desarrollos en los implantes y las inyecciones depot de naltrexona; el jovencito de la escalera se está haciendo mayor
}

\section{Recent developments in naltrexone implants and depot injections for opiate abuse: the new kid on the block is approaching adulthood}

| Colin Brewer ${ }^{\star}$, Emmanuel Streel ${ }^{\star *}$.

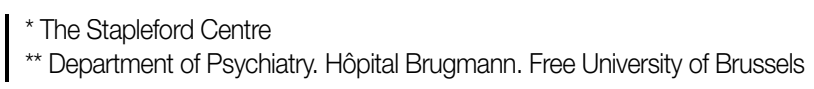

Enviar correspondencia a:

Colin Brewer. The Stapleford Centre. London SW1W 9NP

cbrewer@doctors.net.uk

\section{RESUMEN}

Los implantes y las inyecciones depot (ID) de naltrexona (NTX) han experimentado un notable desarrollo desde que aparecieron los primeros implantes comerciales a mediados de los noventa. Especificamente los implantes de larga duración, capaces de proporcionar NTX en suero con niveles capaces de prevenir las recaidas durante unos 6 meses, han sido sometidos recientemente a las clásicas pruebas con control, con resultados positivos $y$, generalmente, significativamente superiores a la NTX oral o implantes de placebo o tratamientos estándar post desintoxicación. Además proporcionan niveles en sangre suficientes durante varios meses más para prevenir sobredosis por opiáceos. Por otro lado los índices de mortalidad a tres años son similares a los que están en programas de mantenimiento con metadona (PMM). Por lo menos serán necesarios 18 meses de abstinencia con el apoyo de antagonistas para normalizar los nuevos hábitos de comportamiento sin opiáceos y extinguir los viejos hábitos perjudiciales. Se discuten los antagonismos ideológicos que se dan, sobre todo en Australia, entre los protagonistas de PMM y los de implantes de NTX, concluyendo que ambos tipos pueden y deben coexistir. El principal obstáculo para la expansión de los tratamientos con implantes de larga duración no sería pues la falta de evidencia o de base teórica, sino la inexistencia de un fármaco con licencia. NTX parece que bloquea todos los opiáceos si sus niveles en suero son los adecuados; por otro lado debemos tener en cuenta su aparente falta de hepatotoxicidad. Algunos pacientes pueden necesitar niveles en sangre superiores y también puede ocurrir que usuarios habituales de opiáceos por vía venosa continúen inyectándose a pesar de no experimentar los efectos producidos por los opiáceos.

Palabras clave: Naltrexona, implanten, heroina, adicciones, opiáceos, metadona Australia, sobredosis, hepatotoxicidad.
ABSTRACT

Implants and depot injections (DI) of naltrexone (NTX) have undergone considerable development since the first commercially available implants appeared in the mid-1990s. In particular, long-acting implants that can deliver relapse-preventing serum NTX levels for around six months have now been subjected to classic randomised controlled trials that have given positive and generally significant results when compared with oral NTX and placebo implants, or with standard post-detoxification care. They also provide lower serum levels that can prevent opiate overdose for several additional months and 3-year mortality rates are similar to those of methadone maintenance treatment (MMT). At least 18 months of antagonist-assisted abstinence may be desirable to normalise new, opiatefree cognitive-behavioural habits and extinguish old, maladaptive ones. We discuss ideological antagonisms between protagonists of MMT and of NTX implants, notably in Australia, but we argue that both treatments can and should co-exist. The main obstacle to the expansion of longacting implant treatment is not the lack of an evidential or theoretical base but the lack of a licensed product. NTX appears to block all opiates if serum levels are adequate and we stress its apparent lack of clinically significant hepatotoxicity. Some patients may need above-average serum levels and occasionally, habitual injectors continue to inject opiates despite experiencing no opiate effects.

Key Words: Naltrexone, implant, heroin, addiction, methadone, opiate, overdose, hepatotoxicity, Australia. 


\section{INTRODUCTION}

W hen we last wrote about the use of NTX implants and depot injections (DI) for opiate dependence in Adicciones, ${ }^{1}$ only uncontrolled studies had been published. Since then, several controlled trials have appeared. Not surprisingly, given the unfailing effectiveness of NTX as an opioid antagonist, all have given positive results. Most are both statistically significant and of real clinical significance, which is not always the same thing. One important administrative obstacle to the use of implanted NTX in 2003 was the lack of a licensed product. This did not prevent interested clinicians in most countries (including Spain ${ }^{2}$ ) from using implants but it deterred others. However, since 2007, a DI of NTX (Vivitrol) has had a licence for alcoholism treatment and can obviously be used 'off label' for opiate dependence. For most clinicians and medical bureaucrats, such 'off label' use poses fewer ethical and administrative problems than using a product with no licence at all. However, the DI has a relatively short duration of action, 4-5 weeks, compared with the 6-8 weeks of the early implants and the 5-6 months of the Australian GoMedical Implant (GMI), the only long-acting implant (LAI) to have been the focus of controlled clinical trials.

Since LAls have several advantages in treating opioid dependence, they have attracted more research attention than shorter-acting versions. Unusually for a preparation still awaiting a product licence, none of the published academic GMI studies appears to have been funded by the manufacturer. In some cases, as in Australia, academic departments took advantage of the existence of a service that was being provided locally and studied it. In others, as in Norway, previous scepticism about disulfiram implants in alcoholism ${ }^{3}$ caused initially sceptical attitudes to NTX implants in opiate dependence. Given the numerous criticisms about possible bias in studies funded by the pharmaceutical industry, the positive results of controlled studies are therefore doubly impressive. In Russia, the continuing illegality of agonist maintenance for opioid addicts gave a strong incentive to treatment programmes using, first, family-supervised oral NTX with positive results compared with placebo ${ }^{4}$ and then a short-acting implant (SAI) 'Prodetoxona' made in Russia under licence.

SAls usually consist of compressed NTX (base or hydrochloride) mixed with a small amount of magnesium stearate, a traditional ingredient that makes it easier to remove implants intact from their manufacturing moulds. NTX itself has good tissue tolerability (see below) but the stearate can produce typical foreign body giant cell reactions that are not seen in implants made with pure NTX base. ${ }^{5}$ For this reason, some stearate-containing implants incorporate a small amount of triamcinolone to minimise tissue reactions. Release rates and serum levels of NTX from SAls are probably related to the surface area of the implant and are thus at their peak immediately after insertion. As the implant dissolves and becomes smaller, surface area and serum levels fall steadily. To achieve the usual effective target level of at least $1-2 \mathrm{ng} / \mathrm{ml}$ after, say, two months, it is obvious that initial release rates and serum levels will be higher than necessary. Conversely, once the minimal effective level is reached, it may only be a matter of days, or of a week or two, before serum levels become totally ineffective. This re-exposes addicts to the lethal risks of opiate overdose (OOD) if they use again, since they will have lost their tolerance. Similar considerations apply to existing DIs of NTX, which are deliberately designed to deliver most of their NTX load within a four week period and deliver little or none after about five weeks.

The GMI, in contrast to SAls, is made of NTX microspheres coated with a permeable, biodegradable poly-lactide/polyglycolate polymer of the sort that has long been used to make absorbable sutures and orthopaedic screws. The coated microspheres are then embedded in an absorbable polymer matrix. By adjusting the size of the microspheres and the qualities and thickness of the coating and matrix, relatively steady release rates and serum levels can be obtained, since the size and surface area of the implant remain fairly constant for long periods. Furthermore, when serum levels of NTX (and of its moderately active metabolite 6-beta naltrexole) fall below the optimal, they usually remain for several further months at levels that are sufficient to block respiratory depressant effects. Consequently, even before conventional RCTs of LAls were published, convincing evidence emerged of their ability to prevent 00Ds, especially in vulnerable patients who had already needed hospital admission for repeated OODs.

\section{CLINICAL TRIALS OF NTX IMPLANTS AND DIs.}

Hulse et $a l^{6}$ randomised 70 patients to active GMI $(2.3 \mathrm{~g}$ of NTX) and placebo NTX capsules or placebo implant and oral NTX $50 \mathrm{mg} /$ day. In both cases, family members were encouraged to supervise consumption of oral medication. At 6-months follow-up, more implant than oral patients had NTX levels above $2 \mathrm{ng} / \mathrm{ml}(p<0.001) ; 17 \%$ vs $62 \%$ of patients reported regular heroin use; $63 \%$ vs $26 \%$ reported being abstinent ( $p<0.003), 49 \%$ and $21 \%$ respectively being confirmed by urinalysis. Patients on oral NTX started using heroin at an earlier stage (median [SE] 115 [12] vs 158 [9.4] days); NTX levels in implant patients were above 1 and $2 \mathrm{ng} / \mathrm{ml}$ for 101 (95\% Cl 83-119) and 56 (39-73) days respectively for men and 124 (88-175) and 43 (16-79) days for women.

It is important to note that all patients were successfully started on oral or implanted NTX with no dropouts, using an out-patient procedure lasting only a few hours. ${ }^{7}$ The study therefore did not exclude those heroin addicts with unusually severe withdrawal symptoms (or ambivalence) who often discharge themselves prematurely from conventional in-patient or, even more often, out-patient withdrawal programmes. The typical true completion rate even in 'centres of excellence' is less than $30 \% .^{8}$ In contrast, on an 'intention-to-treat' (ITT) basis, 100\% of patients in this study reached this vital stage of treatment 
Kunoe et al. ${ }^{9}$ conducted a multi-centre, open-label study of 56 patients (approximately 85\% heroin injectors) aged $\geq 18$ from various in-patient detoxification programmes in SE Norway and willing to be randomised. If detoxification was completed, they received either normal post-detox care (control) or normal care plus a GMI. Participants were fairly typical of the total population of the 15 clinics. ITT analysis showed significantly less opioid use than controls on all opioid use measures. For example, implant patients used heroin for a mean of 17.9 days (vs 63.6 days for controls) in the 180-day follow-up. Differences were even more significant in the 49 patients who completed treatment. A follow-up study ${ }^{10}$ found that $51 \%$ requested and received a second implant.

Lobmaier et al. ${ }^{11}$ studied imprisoned heroin-related offenders, who are at especially high risk of relapse (and fatal overdose) after release. They compared the effects of GMI or methadone maintenance treatment (MMT) on the use of heroin (and other illicit drugs) and criminality among heroindependent inmates after they left prison. 46 volunteers were randomly allocated to GMI or MMT before release, though they found it unexpectedly difficult to recruit the planned number of inmates willing to be randomised. However, ITT analyses showed reductions in both groups in the use of heroin and benzodiazepines, as well as criminality, six months after prison release. They concluded that NTX implants 'may be a valuable treatment option in prison settings'.

\section{SYSTEMATIC REVIEWS}

In 2008, before any of the above RCTs appeared, Lobmaier et al. published a Cochrane Review ${ }^{12}$. At that time, only one RCT of acceptable quality existed, a DI study comparing two active doses with a placebo injection. ${ }^{13}$ Sixty heroin-dependent adults were randomized to placebo, $192 \mathrm{mg}$ or $384 \mathrm{mg}$ of depot NTX over eight weeks. Doses were administered at the beginning of weeks 1 and 5. Participants also received twice-weekly relapse prevention therapy. Retention in treatment was dose related, 39\%,60\%, and $68 \%$ of patients in the placebo, $192 \mathrm{mg}$, and $384 \mathrm{mg}$ NTX groups, respectively, remaining in treatment at eight weeks. Time to dropout was 27, 36, and 48 days for the placebo, 192 $\mathrm{mg}$, and $384 \mathrm{mg}$ groups, respectively. Adverse events were minimal and generally mild.

A later review ${ }^{14}$ was more positive. Its conclusion that 'long-acting sustained release formulations of naltrexone are well tolerated and more effective for relapse prevention in heroin addicts than the oral ones' might not impress those familiar with the generally disappointing results of oral NTX studies. However, Krupitsky, the principal author, had previously shown that when given under family supervision, oral NTX had significant advantages over placebo, ${ }^{4}$ a finding typical of supervised oral NTX studies. ${ }^{15,16,17}$ (This study also found, interestingly, that routinely adding fluoxetine to NTX treatment was unhelpful for men but might be useful for women.)

\section{OPIOID OVERDOSE PREVENTION}

During the period when an implant provides serum NTX levels at or above the conventional minimal effective range of $1-2 \mathrm{ng} / \mathrm{ml}$, it will generally block all agonist effects of even large doses of heroin and most other opiates, including both the desired euphoriant effects and the dangerous (and usually undesired) respiratory depressant effects. The highest reported medically observed challenge dose involved the administration of $500 \mathrm{mg}$ of pure diamorphine intranasally with no sign of any agonist effects. This is much more than the diamorphine contained in typical individual doses of street heroin used by all but the most severe and well-supplied addicts. The serum NTX level, from a GMI, was $2.9 \mathrm{ng} / \mathrm{ml} .{ }^{18}$ As NTX levels fall, heroin users may eventually obtain a euphoriant effect but it seems that the level needs to fall further still before respiratory depressant effects are seen. This is a very fortunate feature of NTX pharmacology because patients whose opiate receptors have been blocked (or who have simply abstained without NTX) for several months lose their tolerance and risk death or anoxic brain damage if they abuse opiates again. In one Russian case, an implanted patient, abstinent for several months, was employed as a heroin courier precisely because he was assumed to be immune to temptation. However, he tried injecting an unknown but evidently enormous amount of the heroin he was supposed to be selling. He experienced brief unconsciousness and apnoea but recovered spontaneously and completely in a minute or two. ${ }^{19}$ Clearly, the NTX blocked all but the short-lived highest peak of the agonist effects. Without NTX, he would almost certainly not have survived.

It was thus reassuring but not surprising when two GMI studies found large reductions in the expected incidence of OOD for as much as a year after implantation. Hulse \& Tait showed that this was as true for a group of adolescents at high risk for $00 D^{20}$ as for implanted patients in general. ${ }^{21}$ Interestingly, in the latter study, there was an increase in non-opiate sedative overdoses from 8 pre-implantation to 16 afterwards. However, 9 of the 16 occurred in the first week or two after implantation and were probably caused by attempts to deal with the unpleasant withdrawal symptoms (including intractable insomnia) that normally make the period immediately following detoxification by any method such a difficult and relapse-prone stage in treatment.

\section{CAN THE ANTAGONIST EFFECTS OF NTX IMPLANTS BE OVER-RIDDEN?}

The Russian case-report just mentioned reminds us that NTX is a competitive antagonist and can therefore, in principle, be over-ridden by sufficiently high serum levels of agonists. Buprenorphine, with its high receptor-affinity, is the opioid most capable of over-riding the blockade but its intrinsic antagonist effects mean that over-riding carries little or no risk of respiratory arrest. Clearly, even modest NTX levels can block very large amounts of heroin but as with all drugs, some patients will need higher (or lower) 
doses than usual to achieve the desired effects. We recently reported briefly on a case in which a NTX level of only $1.5 \mathrm{ng} /$ $\mathrm{ml}$ blocked a test dose of $500 \mathrm{mcg}$ of $\mathrm{i} / \mathrm{v}$ fentanil but also another patient who showed euphoria and sedation (but not respiratory depression) after smoking no more than about $100 \mathrm{mg}$ of pure diamorphine equivalent despite having a blood NTX level above $4 \mathrm{ng} / \mathrm{ml}^{22}$ However, we stressed that such cases of over-riding are rare and as with all drugs, if the effect is inadequate, increasing the NTX dose and blood level is an obvious therapeutic response.

Hulse et al. ${ }^{23}$ examined the relationship between serum NTX levels, craving and repeated heroin use in a cohort of patients from their 2009 trial of implanted vs oral NTX already described. It found that the risk of $>1=$ weekly heroin use increased by 2.5 times at serum NTX levels $<.5 \mathrm{ng} / \mathrm{mL}$ compared with $>/=.5 \mathrm{ng} / \mathrm{mL}$. Levels $>/=3 \mathrm{ng} / \mathrm{mL}$ were associated with very low risk of use. Whether the reduced risk of heroin use with higher NTX levels represents a direct, pharmacological anti-craving effect or an essentially cognitive, psychological response to the lack of euphoriant effects when these patients tested out the opiate blockade early in treatment (or both) is a matter of both practical and theoretical importance.

\section{TISSUE REACTIONS}

All implant techniques (or even Dls) involve some risk of infection but it should be very low if good sterile procedures are routine. Histological changes over a period of up to 38 months in tissues surrounding GMIs have been studied. They appear to be generally mild, consistent with the many other studies of implanted polymers, and to resolve steadily over time. ${ }^{24}$ A subsequent study ${ }^{25}$ using ultrasound rather than histological techniques, came to similar conclusions. After 24 months, very little implant material was seen.

\section{MENTAL HEALTH AFTER IMPLANTATION}

Lowered mood and energy levels are common in the weeks and months following opiate withdrawal. ${ }^{26}$ The theory that at least some heroin addicts use opiates to self-medicate for underlying mood disorders created understandable concern that prolonged and inescapable blockade of opiate receptors might lead to an increase in depression and/or other psychiatric conditions. Fortunately, a study by $\mathrm{Ngo}$ et $\mathrm{al}^{27}$ found that in 359 patients followed for an average of 1.78 years post-implantation, hospital admission rates for all psychiatric diagnoses declined significantly, except for mood disorders (predominantly depressive rather than manic) which, however, did not show any increase.

\section{DISCUSSION}

NTX is an unusual drug in that it always 'does what it says on the packet'. ${ }^{28}$ In other words, it always blocks the effects of opiates/opioids provided that the blood level of NTX is adequate. Fortunately, this adequate level appears to be relatively low in most cases and can easily be reached or exceeded by available implants or DIs, even if some patients need higher levels than the average. We have briefly reported on a rare but interesting apparent exception to this rule when patients believe they are experiencing breakthrough from injecting heroin despite adequate NTX levels. ${ }^{22}$ In such cases, objective testing with an opiate challenge shows no agonist effects. We call this phenomenon 'pseudo-breakthrough' and surmise that it reflects addiction to the process of injecting, rather than to the substance that is injected. Fortunately, it usually seems to disappear spontaneously if blockade continues for long enough. While BPN needs higher NTX levels than, for example, heroin to displace it from opiate receptors, even BPN can be blocked by appropriate NTX levels. Furthermore, BPN is not, for most opioid abusers, their preferred drug of abuse, especially for the large number of abusers who smoke, swallow or sniff opiates rather than inject them. Not many drugs in any field of medicine are as effective as NTX and even fewer have such a low incidence of significant side effects.

Another unusual feature of NTX treatment is that it has not developed in the classic way, which involves years of evaluation with specific animal models and complex experimental protocols before human applications. Publication of the animal studies may then inspire clinicians to adjust the protocol and develop human models. This was the case when one of us worked on the modulation of opioid withdrawal using up-down-regulation of adrenoreceptors with yohimbine. ${ }^{29}$ However, keeping in mind that the purpose of addiction medicine is not to reduce withdrawal symptoms in opiate-dependent mice, real clinical breakthroughs can sometimes only be achieved when inspired by daily clinical exposure to real patients and sometimes by challenging the prevailing orthodoxies as well. This is exactly what happened with the use of NTX in the modulation of opioid withdrawal. In the late 1980s, Austrian academics tested simultaneously two new methods in opiate withdrawal management: precipitated opiate withdrawal using graduated naloxone and an even shorter detoxification during general anaesthesia using high doses of naloxone. ${ }^{30}$ Both methods shortened detoxification and the use of anaesthesia gave a smoother transition to oral NTX maintenance than previous rapid methods using only oral sedation. ${ }^{31}$ Their approach was indisputably original and helped to confirm the present acceptance that Rapid Antagonist Induction (RAI), with or without anesthesia, is the most effective (and generally cost-effective) method of withdrawal and of starting NTX treatment..$^{32}$ Interestingly, it was a decade later before researchers developed an animal model of RAI in order to better understand its biological mechanisms. ${ }^{33}$ Since then, several studies have led to significant progress in understanding the role of anaesthetic agents in combination with opiate antagonists in modulating withdrawal. This very strange sequence from clinical practice to animal studies ${ }^{34}$ 
forced researchers to seek answers in an unorthodox way but also contributed significantly to the improvement of RAl protocols. This is clinically important because, as we noted in 2003, if patients are to benefit from NTX implants, they must be offered withdrawal techniques that minimize distress and maximize completion-rates. Furthermore, 'completion' of withdrawal in this context means actually starting NTX and not just having completed a standard number of nominally 'opiate-free' days. By that standard, conventional programmes have a long way to go.?

\section{THE MYTH OF NALTREXONE'S HEPATOTOXICITY}

One potential disadvantage of any implanted drug is that if significant side effects of the active constituent occur, the implant may have to be removed. This is of greater concern where DIs are concerned, since it is virtually impossible to remove the intramuscular drug deposit but it is also an important consideration for any still-unlicensed preparation. Fortunately, in some 40 years of clinical use, NTX has yet to be associated with any serious organ toxicity that might limit its prescribing. The only one that is regularly mentioned is hepatotoxicity and a special warning about it still appears in the prescribing literature of most countries where NTX is used. These warnings are misleading and the reason for their existence (and persistence) is not widely known. According to $\mathrm{H}$. Kleber ${ }^{36}$, who was involved in some of the early 1970s clinical studies, there was pressure to change the status of NTX from an experimental drug to one that could be used without too many bureaucratic problems in clinical trials. The pressure originated in the many US servicemen who had started abusing heroin in Viet-Nam and who were expected to need treatment when they returned home. Full toxicity trials had not been concluded but the evidence was reassuring. The authorities agreed in 1972 to easing restrictions on its use, provided that a 'black box' warning about possible hepatotoxicity was included, because some studies had raised concerns. Having entered the official literature, the warning has stayed there, though its justification is now very questionable.

As we noted in 2003, the best evidence for this statement is not the numerous toxicity studies carried out since 1972 but the fact that for nearly 20 years, oral NTX has been used, often for many months and in daily doses much higher than in addiction treatment, to relieve the intense pruritus of severe jaundice. ${ }^{37}$ The high bilirubin levels are due, in most cases, to serious liver disease, sometimes life-threatening. Even if the jaundice is secondary to obstruction, severe biliary stasis itself often causes significant disturbance of liver function tests (LFTs). While NTX use may occasionally be associated with moderately abnormal LFTs, it seems that in none of the reported cases did abnormal LFTs reflect any obvious deterioration in health or lead to any clinical alarm. All abnormalities disappeared rapidly when NTX was discontinued and sometimes even when it was not. Consequently, where there are strong indications for NTX treatment in either opiate or alcohol abuse, the existence of even serious liver disease should not be an automatic contra-indication and the appearance of LFT abnormalities after starting NTX treatment should lead to observation and frequent review rather than to instant termination of treatment. ${ }^{38}$ In real clinical life, NTX appears to have no significant hepatotoxicity.

\section{IDEOLOGICAL ASPECTS OF TREATMENT WITH NTX IMPLANTS}

Addiction treatment often involves moral or ideological arguments that play little part in most other areas of medicine. It is not surprising that those who fundamentally oppose the use of medication in addiction treatment dislike NTX, even in its more effective implanted forms, as much as they dislike MMT. It is less obvious why some NTX prescribers also oppose MMT and why some MMT supporters are very critical of NTX. After all, in most areas of medicine, clinicians offer a range of treatments and 'patient choice' is seen as important. ${ }^{39}$

These wars of ideology are perhaps most apparent in Australia, where some NTX providers apparently feel that MMT is 'wrong' because although it reduces harm, it does not remove pharmacological dependence on opioids. Sometimes, their arguments against MMT are of almost theological bitterness. Conversely, some MMT advocates, citing its 'gold standard' evidence-base, have been very critical of NTX implants with, until recently, only theoretical and empirical evidence of effectiveness. That comparison has now changed. Some opposition may reflect anxiety by prescribers of MMT that support for NTX represents support for an abstinence model of treatment that could reinforce latent prohibitionist tendencies in the government and the public. Finally, it is possible that academics whose reputations and research grants derive from MMT studies, fear that treatment and research funding may be diverted from MMT to NTX. There may also be memories of the way in which, during the late 1990s, the Spanish-Israeli CITA group employed intensive PR techniques to promote rapid opiate detoxification and oral NTX in Australia as something close to a miracle cure. ${ }^{40}$ They failed, partly because of some well-publicised mortality associated with the programme. Given that many opiate-dependent patients say that they would like to escape from their dependence, ${ }_{1}^{41}$ we hope that the increasing evidence-base for NTX implants will soon increase patient choice. Especially since treatment with the GMI appears to have no greater 3-year overall mortality than MMT and avoids the well-documented increased risk of death from OOD during the first two weeks of MMT. ${ }^{42}$

Drug-free residential programmes are usually unwilling, on ideological grounds, to offer patients the relapsepreventing benefits of NTX implants when they leave the protected environment of the clinic. Yet newly-discharged patients have to confront and resist the temptations of real life and often have to return to their usual home, where 
they may meet old friends and dealers. This situation carries a high risk of OOD. Ravndal and Amundsen found a 15-fold increase in the Standard Mortality Rate in the first four weeks after discharge, ${ }^{43}$ all due to OOD. Most deaths could have been prevented by the use of a GMI. Furthermore, as we have previously emphasised, LAls not only prevent relapse through 'Antagonist-Assisted Abstinence' (AAA) but also promote and reinforce desirable cognitive and behavioural changes by requiring patients to respond to opiate-related cues in ways that cannot involve experiencing opiate agonist effects. A similar process of cognitive and behavioural change has been reported with long-term alcoholism treatment programmes incorporating supervised disulfiram. ${ }^{44}$ It supports our previous suggestion that a minimum period of between one and two years of AAA is usually needed for such changes to become well established and automatic. LAls of NTX are a simple, reliable and safe way of providing consistent AAA. If we had similar long-acting antagonists or vaccines against other major drugs of abuse, we could help many more of our substance-abusing patients.

\section{Conflict of interest statement.}

ES has no conflicts to declare.

$\mathrm{CB}$ derives some income from a clinic that offers agonist and antagonist treatments. He has given unpaid advice to both agonist and antagonist manufacturers but has never had any financial links with them.

\section{REFERENCES}

1. Brewer C, Streel E. Naltrexone implants: a real therapeutic advance, both behavioural and pharmacological. (Implantes de naltrexone: un avance terpaeutico, tanto comportamental como farmacologico.) Adicciones 2003; 15(4) 299-308

2. Carreno JE, Alvarez CE, Narciso GI, Bascaran MT, Diaz M, Bobes J. Maintenance treatment with depot opioid antagonists in subcutaneous implants: an alternative in the treatment of opioid dependence. Addiction Biology. 2003:8(4):429-38.

3. Jonsen J, Mørland G. Depot preparations of disulfiram: experimental and clinical results. Acta Psychiatrica Scandinavica 1992;86:27-30.

4. Krupitsky EM, Zvartau EE, Masalov DV, Tsoy MV, Burakov AM, Egorova VY, Didenko TY, Romanova TN, Ivanova EB, Bespalov AY, Verbitskaya EV, Neznanov NG, Grinenko AY, O'Brien CP, Woody GE. Naltrexone with or without fluoxetine for preventing relapse to heroin addiction in St. Petersburg, Russia. E. J Subst Abuse Treat. 2006 Dec;31(4):319-28.

5. Partecke L. Personal communication.

6. Hulse GK, Morris N, Arnold-Reed D, Tait RJ. Improving clinical outcomes in treating heroin dependence: controlled trialof oral or implant naltrexone. Arch Gen Psychiatry, 2009 0ct: 66(10):1108-15

7. Arnold-Reed DE, Hulse GK. A comparison of rapid (opioid) detoxification with clonidine-assisted detoxification for heroin-dependent persons. Journal of Opioid Management. 2005;1(1):17-23.

8. Strang J, Mc Cambridge J, Best D, Beswick T, Bearn J, Rees S, et al. Loss of tolerance and overdose mortality after inpatient opiate detoxification: follow up study. British Medical Journal. 2003;326:959-60.

9. Kunoe $N$, Lobmaier $P$, Vederhus JK, Hjerkinn B, Hegstad $S$, Gossop $M$, et al. Naltrexone implants after in-patient treatment for opioid dependence: randomised controlled trial. Brit J Psychiat. 2009;194:541-6.

10. Kunoe N, Lobmaier P, Vederhus JK, Hjerkinn B, Hegstad S, Gossop $\mathrm{M}_{1}$ et al Retention in Naltrexone implant treatment for opioid dependence. Drug Alc Depend 2010 in press

11. Lobmaier PP, Kunøe N, Gossop M, Katevoll T, Waal H. Naltrexone Implants Compared to Methadone: Outcomes Six Months after Prison Release. Eur Addict Res. 2010 Apr 26;16(3):139-145.

12. Lobmaier P, Kornør H, Kunøe N, Bjørndal A. Sustained-release naltrexone for opioid dependence. Cochrane Database Syst Rev. 2008 Apr 16;(2):CD006140.

13. Comer SD, Sullivan MA, Yu E, Rothenberg JL, Kleber HD, Kampman K, Dackis C, O'Brien CP. Injectable, sustainedrelease naltrexone for the treatment of opioid dependence: $a$ randomized, placebo-controlled trial. Arch Gen Psychiatry. 2006 Feb;63(2):210-8

14. Krupitsky EM, Blokhina EA.Long-acting depot formulations of naltrexone for heroin dependence: a review. Curr Opin Psychiatry. 2010 Mar 10.

15. Chan KY. The Singapore naltrexone community-based project for heroin addicts compared with a drug-free communitybased programme: the first cohort. Journal of Clinical Forensic Medicine. 1996;3:87-92.

16. Cornish J, Metzger D, Woody G, Wilson D, Mclellan T, Vandergrift $B$, et al. Naltrexone pharmacotherapy for opioid dependent federal probationers. Substance Abuse Treatment. 1997;14(6):529-34.

17. Hulse GK, Basso MR. The association between naltrexone compliance and daily supervision. Drug and Alcohol Review. 2000;19:41-8.

18. Brewer C. Serum naltrexone and 6-beta-naltrexol levels from naltrexone implants can block very large amounts of heroin: a report of two cases. Addict Biol. 2002.7:

19. Krupitzky E, Burakov A, M. V. Tsoy M, Egorova V, Slavina T, Grinenko A, Zvartau E, Woody G. Overcoming opioid blockade from depot naltrexone (Prodetoxon ${ }^{\circledR}$ ) Addiction, 2007. 102 (7) July, 1164-1165

20. Hulse G. Tait R. A pilot study to assess the impact of naltrexone implant on accidental opiate overdose in 'high risk' adolescent heroin users. Addiction Biology 2003; 8 (3) 337-342.

21. Hulse $G$, Tait $R$, Comer $S$. et al. Reducing hospital presentations in opioid overdose in patients treated with sustained release naltrexone implants. Drug Alc Depend. 2005; 79: 351-357

22. Brewer C, Streel E. Current issues in the use of opioid antagonists. In: (Eds: Reginald L. Dean III, Edward J. Bilsky and S. Stevens Negus III.) Opioid Receptors and Antagonists: From Bench to Clinic. Contemporary Neuroscience series. Wiley. NY. 2009

23. Hulse GK, Ngo HT, Tait RJ. Risk Factors for Craving and Relapse in Heroin Users Treated with Oral or Implant Naltrexone. Biol Psychiatry. 2010 In press. 
24. Hulse GK, Stalenberg V, McCallum D, Smit W, O'Neil G, Morris $N$, et al. Histological changes over time around the site of sustained release naltrexone-poly(DL-lactide) implants in humans. Journal of Controlled Release. 2005;108:43-55.

25. Hulse GK, Low VHS, Stalenberg V, Morris N, Thompson RI, Tait RJ, et al. Biodegradability of naltrexone-poly(DL) lactide implants in vivo assessed under ultrasound in humans. Addiction Biology. 2007;13:364-72.

26. Eklund, C. Withdrawal from methadone maintenance treatment in Sweden. Introduction, p.9-10. Uppsala University Press, 1996.

27. Ngo HTT, Tait RJ, Arnold-Reed DE, Hulse GK. Mental health outcomes following naltrexone implant treatment for heroindependence. Progress in Neuro-Psychopharmacology \& Biological Psychiatry. 2007;31:605-12.

28. Brewer C. RESPONSE TO: Opioid overdose deaths can occur in patients with naltrexone implants, Gibson A, Degenhardt L, Hall W. (Original in Med J Austral 2007; 186 (3): 152-153)

29. Streel E, Dan B, Campanella S, Meyvaert A, Hanak C, Pelc I, Verbanck P. 2006. A pharmacological modulation of opiate withdrawal using an up-/down-regulation of the noradrenergic system in opiate-dependent rats. Int J Neuropsychopharmacol.;9(5):621-6.

30. Loimer N, Presslich O, Lenz K, Pfersmann D, Schmid R, Fodor G, Aschauer G. 1989.Induced detoxification treatment" of opiate dependent patients--a new therapy concept. Wien Klin Wochenschr. 23;101(13):451-4.

31. Brewer C. Ultra-rapid, antagonist-precipitated opiate detoxification under general anaesthesia or sedation. Addiction Biology 1997;2:291-302

32. Shanahan MD, Doran CM, Digiusto $E$, Bell J, Lintzeris N, White J, Ali R, Saunders JB, Mattick RP, Gilmour S.A costeffectiveness analysis of heroin detoxification methods in the Australian National Evaluation of Pharmacotherapies for Opioid Dependence (NEPOD). Addict Behav. 2005 Jun 20;

33. Streel E, Bredas P, Dan B, Hanak C, Pelc I, Verbanck P. 2000. Previous anesthesia can temporarily overshadow the expression of a withdrawal syndrome in opiate dependent rats. Life Sci. 27;67(23):2883-7.

34. Streel E, Verbanck P.(2003). Ultra-rapid opiate detoxification: from clinical applications to basic science. Addict Biol. 8(2):141-6.

35. Arnold-Reed DE, Hulse GK. A comparison of rapid (opioid) detoxification with clonidine-assisted detoxification for heroindependent persons. J Opioid Manag. 2005 Mar-Apr;1(1):17-23.

36. Kleber H. Personal communication

37. Terg R, Coronel E, Sorda J, Munoz AE, Findor J. 2002. Efficacy and safety of oral naltrexone treatment for pruritus of cholestasis, a crossover, double blind, placebo controlled study. J Hepatol, 37(6): 717-722.

38. Brewer C, Wong V-S Naltrexone: a case report of lack of hepatotoxicity in acute viral hepatitis, with a review of the literature. Addiction Biology 2004; 9: 81-7.

39. Brewer C. Harm-reduction for unwanted pregnancies and unwanted addictions: an instructive analogy. Adicciones, 2008;20(1):5-13

40. Brewer C, Williams J, Carreño E, Bobes J. Unethical promotion of rapid opiate detoxification under anaesthesia (RODA). (Letter) The Lancet 1998;351:218

41. McKeganey N, Morris Z, Neale J, Robertson M. What are drug users looking for when they contact drug services: abstinence or harm reduction? Drugs: Education, Prevention and Policy. 2004;11:423-5.

42. Tait RJ, Ngo HT, Hulse GK.Mortality in heroin users 3 years after naltrexone implant or methadone maintenance treatment. $J$ Subst Abuse Treat. 2008 Sep;35(2):116-24.

43. Ravndal E, Amundsen EJ. Mortality among drug users after discharge from inpatient treatment: an 8-year prospective study. Drug Alcohol Depend. 2010 Apr 1;108(1-2):65-9

44. Krampe $H$, Ehrenreich $H$. Supervised disulfiram as adjunct to psychotherapy in alcoholism treatment. Curr Pharmaceut Design, 2010, 16, 2076-90. 
